\title{
Reading Comprehension and Tolerance against Comprehension Ambiguities: An Empirical Study of Iranian GFL-Learners in Communicative Education
}

\author{
Nader Haghani ${ }^{1,2}$ \& Fereshteh Bahmannejad ${ }^{2}$ \\ ${ }^{1}$ Research Institute ReCeLLT, University of Tehran, Tehran, Iran \\ ${ }^{2}$ Faculty for Foreign Languages and Literatures, University of Tehran, Tehran, Iran \\ Correspondence: Nader Haghani, Research Institute ReCeLLT, University of Tehran, Tehran, Iran; Faculty for \\ Foreign Languages and Literatures, University of Tehran, Tehran, Iran. E-mail: nhaghani@ut.ac.ir
}

Received: August 5, 2017

Accepted: August 14, 2017

Online Published: August 23, 2017

doi:10.5539/jel.v7n1p1

URL: https://doi.org/10.5539/jel.v7n1p1

\begin{abstract}
The present study examines the influence of ambiguity tolerance on the performance of Iranian GFL-learners (Note 1) at level B1 in the processing of gap-filling-text tests. It is assumed that learners with more tolerance of ambiguity achieve better results in the reading comprehension or in the contextual guessing of the omitted words. 34 GFL learners at Level B1 in Iran Language Institute in Mashhad have completed a three-part pilot gap-filling test as well as the pilot questionnaire called SLTAS (Note 2) to assess their ambiguity tolerance. In order to examine the hypothesis and to answer the research question, the total score of the subjects who participated in the pilot and the main study were analyzed by SPSS program version 18.0. The quantitative-correlative analysis did not demonstrate a statistically significant relationship between the tolerance of ambiguity and reading comprehension. In conclusion, with regard to the multi-dimensionality of reading comprehension, and despite the divergent empirical evidence in research literature, it is still advisable to take into account the affective, cognitive, and extra-linguistic determinants of reading comprehension in further empirical studies from various aspects and to greater extents. This study provides suggestions for the recognition of the interaction between different affective, and cognitive influential factors in the multidimensional reading process, as well as a basis for the teachers' and linguists' methodology with respect to learners in terms of their individual differences while instructing reading comprehension in German as a foreign language.
\end{abstract}

Keywords: ambiguity tolerance, gap-filling test, reading comprehension, SLTAS

\section{Introduction}

As a result of a shift of emphasis from language teaching methodology to language learners and learning variables in the last few years, which greatly influenced language learning, the individual differences and learning styles gained in significance since they promise a considerable success on the part of learners (Başöz, 2015). In order to design more effective teaching strategies, teachers need to recognize the differences between learners from different individual aspects, such as age, gender, motivation, anxiety, self-awareness, ambiguity tolerance, risk tolerance, willingness to cooperate, competitiveness, and language learning strategies and styles (Oxford, 1992). Changes in the methodology of research have brought about a shift of significance now attached to the reader rather than the text. Thus the activities of the reader, his interest, his previous knowledge and his strategies are important for reading in the foreign language (Schrader, 1996). Therefore, it can be assumed that cognitive, affective factors influence reading comprehension. Covington (1997) introduces the hypothesis of affectology, according to which cognitive functions are never completely affect-free and affects never completely cognition-free. The findings of neuropsychological reading research also show that right-hemispheric-controlled feelings strongly determine reading comprehension. They are crucial in the initiation and steering of the interpretative activities associated with the reading process (Miall, 1995).

In addition to affective factors, there are linguistic forms and textual structures with which the learners deal in order to have a successful reading comprehension. They also need to cope with their incomplete background knowledge (Carrell \& Eisterhold, 1983; Carrell, 1987; Alderson, 2000) and to compensate for the lack of essential elements to meet the reading comprehension task (Grabe \& Stoller, 2002). Moreover, readers from 
different cultural backgrounds have different expectations and experiences in the language environment, which could lead to the establishment of common meanings. Learners are also overwhelmed with new information, which is processed, recorded and connected with the existing knowledge. Establishing a relationship between existing knowledge and new information is not an easy task because there is no one-to-one relationship between the structures, lexical items, and phonological and phonetic elements between the two languages. Regardless of whether learning takes place in the classroom or in the natural language environment, whether for communicative use or for personal reasons, the learner has to effectively deal with many inconsistencies due to lack of conformity between the individual languages. A characteristic, which can help the learner to cope with these uncertainties inherent in foreign language learning, is ambiguity tolerance (Kazamia, 1999). Ambiguity tolerance is the acceptance of confusing situations. Learning a foreign language means confronting many uncertainties about the meanings, referents and pronunciation, says Ely (1989). This type of tolerance applies to the degree to which the individual is cognitively willing to tolerate ideas or propositions that are at odds with his or her own belief system or knowledge structure (Brown, 2000). If the learners are intolerant of ambiguities, they tend to describe ambiguous stimuli as a source of threat, as they sound new, complex, or unsolvable. Consequently these learners are reluctant to accept new stimuli, analyze complicated data, or deal with cases that are contradictory. On the other hand, the more ambiguity-tolerant learners are willing to meet new complex, and unsolvable situations. They are receptive to change and are willing to take risks (McLain, 1993). The person with a high ambiguity tolerance is open to innovative, creative possibilities and is not disturbed cognitively and affectively by ambiguities and uncertainties. This degree varies according to the learning style or the linguistic situation (Atef-Vahid, Fard Kashani, \& Haddadi, 2011). Ehrman (1996) suggests that effective language learning is rather a process of reinterpretation of reality as an alternative perspective (p. 177). The language learning process is severely hampered if one is reluctant to accept that a word in the target language contains multiple denotations. Besides one does not need to know the meaning of all vocabularies in a text to understand a passage (Ely, 1995, p. 88).

Reading comprehension is the grasping of the core meanings of a text from the context through prior knowledge of the subject, worldviews and assumptions. In the presumptive reading, readers are required to apply more complex processing strategies. Text-based hypotheses are made about the text while reading, which may be confirmed or discarded after the process. This allows the reader to decide whether the text remains coherent and assists him or her while completing the gaps in the case of a gap-filling test (Mashkovskaya, 2013). The hypothesis theory is a useful reference theory for understanding processes in reading comprehension (Bruner \& Postman, 1951; Lilli \& Frey, 1993). Bruner and Postman (1951) have developed a theory whose central focus is that every perception process begins with a cognitive predisposition or hypothesis (Lilli \& Frey, 1993, p. 51). Based on earlier cognitions and perceptions, perceptual-expectational hypotheses are generated which selectively control perception and attention and indicate the likelihood of the appearance of certain phenomena or characteristics. In the case of hypothesis theory, the procedural conditions of the emergence of social perceptions are taken into account. An analysis unit is the relationship between the participants' perception, experience and planning perspectives, and the respective perceived situation. The cognitive interaction between the reader and the text takes place through the interpretation, design and understanding of the stimulation situation or the text on the basis of available hypotheses (Finkbeiner, 2005, p. 190). Readers participate in the process of meaning-extraction by means of the texts or the contextual clues. They understand not only the meaning in the given text, but also the relevant grammatical patterns, common lexical phrases, and typical associations of the words within the context since learners see chunks of words rather than individual vocabularies (Ying, 2001).

A common survey tool for evaluating linguistic performance by means of reading comprehension is a reduced redundancy test, which is also used in the present study to evaluate reading comprehension. This approach to linguistic evaluation was recommended for the first time by Spolsky, Bengt, Sako and Aterburn (1968) and forms the basis for the development of various test methods such as Cloze tests, $\mathrm{C}$ tests, dictation, etc. The phenomenon of reduced redundancy is to be found in any linguistic or verbal context in which the disambiguation of incomplete or disordered messages is possible through prognosis or contextual clues. Since ambiguities are inherent components of foreign-language reading and in particular of reading comprehension, in the context of the reduced redundancy tests, ambiguity tolerance can be regarded as a significantly relevant variable of influence. Among the cognitive styles, there is evidence that field independence and ambiguity tolerance affect the performance of learners in certain assessment tests (Bachman, 1990). Ambiguity tolerance and field independence apparently affect the scores in C tests and Cloze tests. Inevitably, the use of a reduced redundancy principle results in a garbled incomplete text, which challenges the test participants with a certain degree of ambiguity until the text is returned to its entirety or till it is synthesized. Such tests are considered as 
integrative tests and are expected to cause the general processing of the related context-dependent parts, resulting in different performances of field-dependent or independent test participants (Babaii \& Shahri, 2010). Bachman (1990) postulates that the individuals with higher ambiguity tolerance are expected to perform well in the Cloze tests, where several correct answers and alternative correct interpretations are often possible and in which the correctness of the solutions entered into the gaps is only called into question when one reads through the text passages (p. 277). In general, it is assumed that ambiguity tolerance as a psychological advantage with a particular strengthening effect helps the reader to deal successfully with the unexpected and frightening, oppressive situations as with a test apart from the nature of the applied test. With this conceptualization, ambiguity tolerance is defined as a component of strategic competence (Bachman \& Palmer, 1996), which is one of the metacognitive strategies that encompass higher and executive processes that provide cognitive administration in language usage and other cognitive activities. It seems that all language tests, as kinds of ambiguous situations in general and regardless of their types and format, rely to a certain extent on cognitive supervision. Therefore, tolerance of ambiguity is an advantage not only in reduced redundancy testing, but also in dealing with the recognition tasks (ibid.).

The absence of proper performance in reading comprehension may be due to low linguistic competence, but one cannot rule out the role of the negative influence of intolerance against the ambiguities. Hence, research on their impact on reading comprehension, which is to be regarded as a multidimensional process, can help provide a more realistic view of the influential factors in comprehension of a text. Although many researches have shown the effect of variants mentioned on the performance in some test types (e.g., Ely, 1989; Lee, 1999; El-Koumy, 2000; Erten \& Topkaya, 2009; Karbalaee Kamran \& Maftoon, 2012; Shakeri, 2012), there is no research in this context with Iranian learners who learn German as a foreign language. By considering the influence of context on the relationship between reading comprehension and the affective, cognitive variables (Lustig \& Koester, 1993; Brantmeier, 2002), it seems beneficial to investigate the previous researches in this field and to replicate such researches with relevance to the predictors of the reading comprehension in a German classroom context with the Iranian learners, who are learning German as a foreign language.

The present study aims at the discovery of a significant relationship between ambiguity tolerance of a limited number of B1 Level Iranian GFL learners and their performance in linguistic tests corresponding to their linguistic level. The research question and the hypothesis are:

Research question: Is there a statistically significant relationship between the ambiguity tolerance of Iranian GFL learners and their achievements in reading comprehension?

Hypothesis: There is a statistically significant relationship between the ambiguity tolerance of Iranian GFL learners and their performance in reading comprehension.

\section{Method}

The design of the present study is descriptive and correlative. According to Cronbach (1987), correlation research is based on relationships between two or more characteristics. In this study, data analysis was performed by descriptive statistics and inferential statistics. The mean values, the standard deviations and the standard errors of the mean values were measured in the descriptive statistics. The reliability of the research instruments was measured by Cronbach Alpha in SPSS 18. The Pearson correlation analysis was used to provide the interference statistics. This makes it possible to investigate the significance of the correlation between the ambiguity tolerance and the score in the reading comprehension of the subjects.

\subsection{Participants}

The subjects of the present study, which took place in the autumn of 2015, were a total of 43 young GFL learners ( 9 subjects in the pilot study and 34 subjects in the main study) in the age group from 18 to 35 at the Iran Language Institute (ILI) in Mashhad. Three young men (33.3\%) and 6 young women (66.7) participated in the pilot study, while 5 men (14.7\%) and 29 women (85.3\%) participated in the main study. Among the subjects in the pilot study were 4 unemployed (44.4\%), 4 students (44.4\%) and an employed (11.1\%). $11.8 \%$ of the subjects in the main study (4 participants) were the unemployed. Among them were $41.2 \%$ (14 participants) students and 16 participants and $47.1 \%$ were employed. Their language skills corresponded to level B1 according to the guidelines of the common European reference framework. This was proved by the Goethe Institute's (2015) placement test limited to "reading". All subjects in this study have learned German as a foreign language in the communicative teaching context of the Iran Language Institute (ILI) in the amount of 378 lessons. Foreign language teaching is offered in the ILI under institutional conditions, with program specifications and a specific methodology and didactics. 


\subsection{Instrumentations}

In order to ensure the reliability of the research instruments, a pilot study was carried out in which 9 subjects participated in the reading comprehension tests under the same conditions as in the main study. The Persian version of the questionnaire "SLTAS" was adapted so as to be suited for German language. The translation of the questionnaire was made by the author of the present study. In order to ensure the validity of the Persian version, the items of this questionnaire were corrected by Omid Hamedani, a professor of Persian Language and Literature at the University of Ferdowsi in Mashhad. The appendix contains the German and Persian versions of the questionnaire "SLTAS". In order to achieve the purpose of the study, the following data collection tools were used in two phases (pilot study and main study):

1) Demographic issues (age, sex, occupation and foreign languages).

2) Placement test (only testing reading comprehension skills) and selection of level B1 students. The model set of the Goethe Zertifikat B1/German Examination for Adults and Young People (Goethe Institut, 2015) was used for this purpose.

3) Three B1 level gap-filling tests for measuring reading comprehension.

4)The questionnaire SLTAS by Ely (1995) for the measurement of the ambiguity tolerance of the subjects.

SLTAS is the only questionnaire in this field which has been conceived exclusively for the measurement of the ambiguity tolerance of language learners in the communicative language context. In the development of the scale, he intended to implement a situation-specific approach, taking account of the ambiguity tolerance. The responses are in Likert scale format with a series of five replies including "strongly agree", "agree", "undecided", "disagree" and "strongly disagree" each of which are assigned scores of 5, 4, 3, 2, 1 respectively. The higher the score, the more intolerant the subjects are. The aim of using these items is to assess the consistency of the subjects with the elements in the test that express the ambiguity intolerance in the given situations.

\subsection{Procedure}

The following procedure was used to determine the research data: First, the reading comprehension test with gaps and the questionnaire on the ambiguity tolerance (SLTAS) were carried out on 9 subjects ( 3 males and 6 females). They had nearly the same characteristics as the target group. This pilot study was used to evaluate the hypothesis and to identify possible problems and confounding factors before the main study. It should be mentioned that all participants of the study were B1 level students who were selected after they had successfully passed a grading test. For this purpose the model set of "Goethe Zertifikat B1/German Examination for Adults and Young People" (Goethe Institut, 2015) was used. The "Reading" skill has been tested. A maximum of 100 points could be reached. The pass mark was 60 points, i.e., $60 \%$. The test situation was simulated and the time was equal to the original test conditions or 65 minutes. The reading comprehension test, which consists of three gaps, was taken from the "ZD-Exercise Test 1 of the Telc-German B1" for preparation for the examination "Zertifikat B1" (Telc gGmbH, 2014, p. 13) and from the certificate training part of the course book "Studio d" (Funk et al., 2007, p. 201). The participants had thirty minutes to complete the gaps. Cronbach's alpha of the texts was 0.739 that is over 0.7 and therefore reliable.

The subjects had fifteen minutes time to complete the questionnaire "SLTAS". Cronbach Alpha of this test was also 0.738 and therefore acceptable. In the next step, the questionnaire and the gap-filling tests were carried out at three intervals in the main study with three B1 groups (a total of 34 subjects) selected according to the above-mentioned classification test. The male subjects (5 participants) had $14.7 \%$ and the female subjects (29 participants) constituted $85.3 \%$ of the main group. The reason for the lower number of men compared to women in this study is that, in general, apparently more female students participate in German courses in institutes. Subjects in all groups of the pilot study and the main study received the necessary explanations and instructions for the completion of questionnaires and gaps. They were also drawn to the fact that there is no right or wrong answer. It is worth mentioning that the subjects were encouraged to provide accurate, honest answers. They were also notified that the information they provide is only used to collect data for the research purpose and that only the researcher has access to them. The time -15 minutes to complete questionnaires and 30 minutes to complete gaps- was announced and executed. Finally, the statistical analysis was carried out to find out whether there was a statistically significant interaction between ambiguity tolerance and reading comprehension.

\section{Results}

As a result of piloting these instruments, the mean value, the standard deviation of the raw values and their reliability were measured. The coefficient of reliability is between zero and one. The higher this number tends to 
be, the more is the reliability of the questionnaire concerned. In this research the Cronbach-Alpha method was used as the standard setting and the most common criterion of reliability. The result of the reliability analysis of all research instruments was satisfactory according to the guideline by Vogt (2007), since as specified by him, an alpha value of 0.70 and more is considered satisfactory for most purposes in an examination (p. 115).

Table 1. Descriptive statistics of variables in the pilot study

\begin{tabular}{llllll}
\hline Variables & N & Minimum & Maximum & Mean & Standard deviation \\
\hline Reading score & 9 & 22 & 36 & 30.222 & 4.8933 \\
Tolerance of ambiguity & 9 & 2.25 & 4 & 3.3333 & 0.6038 \\
\hline
\end{tabular}

Table 2. Descriptive statistics of variables in the main study

\begin{tabular}{llllll}
\hline Variables & $\mathbf{N}$ & Minimum & Maximum & Mean & Standard deviation \\
\hline Reading score & 34 & 21 & 46 & 37.235 & 8.832 \\
Tolerance of ambiguity & 34 & 1.75 & 4.33 & 2.863 & 0.609 \\
\hline
\end{tabular}

To measure the hypothesis of normality of variables, the Kolmogorov-Smirnov test was utilized in this research. The statistical hypotheses of the normality test "Kolmogorov-Smirnov test" are as follows:

Hypothesis H_0: The data are normally distributed.

Hypothesis $\mathrm{H}_{-}(1)$ : The data are not normally distributed.

The results of the Kolmogorov-Smirnov test are shown in the following tables.

Since the significance level of the tests is above 0.05 for all variables, the assertion of the normality of the data is assumed and all variables have normal distribution, so the parametric methods can be used to analyze the research hypotheses.

Table 3. Sample test Kolmogorov-Smirnov test in the pilot study

\begin{tabular}{lll}
\hline & Reading score & Tolerance of ambiguity \\
\hline Number & 9 & 9 \\
Kolomogrov-Smirnov Z & .779 & .833 \\
Asymp. Sig. (2-tailed) & .579 & .491 \\
\hline
\end{tabular}

Table 4. Sample test Kolmogorov-Smirnov-Test in the main study

\begin{tabular}{lll}
\hline & Reading score & Tolerance of ambiguity \\
\hline Number & 34 & 34 \\
Kolomogrov-Smirnov Z & 1.279 & .653 \\
Asymp. Sig. (2-tailed) & .076 & .787 \\
\hline
\end{tabular}

In this part the hypotheses are examined. Because of the normality of the variables, the parametric methods of "Pearson Correlation Analysis" are used to check the hypotheses. The following table shows the Pearson Correlation between ambiguity tolerance of Iranian GFL learners and their achievements in reading comprehension, which is $(r=0.504)$ and partly positive. The significance level of the test in the pilot study is 0.166 , which is above 0.05 . Therefore, the empirical hypothesis is rejectable with $95 \%$ certainty, which means that there is no statistically significant relationship between the ambiguity tolerance of Iranian GFL-learners and their performance in reading comprehension. Crobach Alpha of the questionnaire and the gap-filling test is 0.754 and over 0.7 . Therefore, their reliability, according to Vogt (2007, p. 115), is justifiable. 
Table 5. Correlation between reading score and tolerance of ambiguity in the pilot study

\begin{tabular}{lll}
\hline & & Tolerance of ambiguity \\
\hline \multirow{3}{*}{ Reading score } & Pearson correlation & .504 \\
& Sig. (2-tailed) & .166 \\
& Number & 9 \\
\hline
\end{tabular}

Table 6. Correlation between reading score and tolerance of ambiguity in the main study

\begin{tabular}{lll}
\hline & & Tolerance of ambiguity \\
\hline \multirow{3}{*}{ Reading score } & Pearson correlation & -.011 \\
& Sig. (2-tailed) & .950 \\
& Number & 34 \\
\hline
\end{tabular}

This table shows the Pearson correlation between the ambiguity tolerance of Iranian GFL learners and their performance in reading comprehension in the main study, which is -0.011 and partially negative. The significance level of the test is $(\mathrm{r}=0.950)$, which is over 0.05. $(\mathrm{Sig}=.950>0.05)$. Therefore, the research hypothesis is to be rejected with $95 \%$ certainty, which means that there is no statistically significant relationship between the ambiguity tolerance of Iranian GFL-learners and their achievements in reading comprehension. Hence the research hypothesis is rejected.

\section{Conclusion and Discussion}

Whereas there have been similar studies whose results manifest a significant correlation between ambiguity tolerance and reading comprehension, the obtained results of this study, with regard to the research questions and based on the statistical data analysis, show no significant correlation between these two. To achieve pedagogical implications, it is deemed advisable to discuss some of the influential factors which may have caused the achievement of the unexpected findings.

In interpreting the results obtained, it is necessary to consider the respective contribution of features that are reader-specific (Artelt et al., 2007). The affective, cognitive, and metacognitive factors influence the reading process. It is therefore appropriate to check the influence of ambiguity tolerance on the reading comprehension process. Nevertheless, one should not ignore the role of other affective, cognitive factors in the reading process. Reading comprehension is, in fact, a multidimensional process that can be influenced by a variety of factors, and it is impractical to include only the action of some limited variables. This could cause failure in the realization of the expected effects.

The sheer fact that the sample size was small is probably one of many reasons as to why the desired results were not obtained. As can be seen in the arguments of Pallant (2011), the sample size must be taken into account when interpreting the significance of values achieved. One must be mindful that even big correlations cannot play a statistically significant role in small sample groups, whereas even very small correlations are significant in large groups. Therefore, it is essential to focus on the strength of the relation and the scope of the common variance.

With respect to the findings of this study, which show a statistically positive but insignificant correlation between ambiguity tolerance of the subjects and their score in the reading comprehension, it is perceived that the reading comprehension improves when ambiguities are tolerated even though this correlation is not significant. In other words, the resultant number is not great enough to invalidate the probability of its accidentality. This result contradicts some previous relevant studies (e.g., El-Koumy, 2000; Erten \& Topkaya, 2009; Karbalaee Kamran \& Maftoon, 2012; Keshavarz \& Assar, 2009), whose correlative analyses indicate a strong correlation between ambiguity tolerance and self-evaluated success in reading a foreign-language text. This result is also in contradiction with the research findings of Brown (2000), Ely (1989) and White (1999), which explain the positive influence of ambiguity tolerance on linguistic development in general. The study by Shakeri (2012) is consistent with the results of this research, in which there was no significant relationship between ambiguity tolerance of the subjects and their performance in reading comprehension. Chapelle and Roberts (1986) also found no significant correlation between ambiguity tolerance and linguistic skills at the beginning of the 
semester. This result corresponds in particular to the skill of "reading" and the findings of the present study. The results of one other study on the relationship between ambiguity tolerance and Cloze test performance (Atef-Vahid et al., 2011) are in contradiction with the results of the present study showing the existence of a significant relationship between ambiguity tolerance levels of subjects and their performance in the Cloze test.

Parallel to the results of Atef-Vahid et al. (2011) and in contrary to the present study the study of Babaii and Shahri (2010) confirms that field dependence and ambiguity tolerance as two cognitive styles have a significant effect on the $\mathrm{C}$ test and Cloze test performance of EFL students although no significant difference was found between C-test and Cloze test for their interaction with field dependence and ambiguity tolerance. Despite the existence of many parallel researches in this area (e.g., Isen, 1984; Arnold \& Brown, 1999; Finkbeiner, 1997, 2001a, 2001b; Arnold, 2011), which authenticate the role of affective and cognitive factors in the reading-comprehension process as positive predictors, there is the risk of overestimation or over-generalization of the influence of ambiguity tolerance and other affective person-specific factors on reading comprehension.

Despite rejecting the existence of significant effects of ambiguity tolerance on reading comprehension, or the performance of the subjects in supplementing the gaps in the text in this study, the important role of the mentioned potential influential factors in the reading comprehension must not be neglected with regard to the limitations of the present research as well as in view of the results of parallel researches in the English-speaking world. It would certainly be profitable to pave the way for language learners with a lower ambiguity tolerance level to present themselves more successfully in tasks such as gap-filling tasks, which demand a certain degree of guessing and tolerance against uncertainties. If teachers allow the learners to familiarize themselves with the existing cognitive and affective factors and their effects on the performance on completing the gaps as a representative presentation of the tasks which demand reading comprehension, then the learners are able to determine the disposition of the ambiguous situations and thus try to overcome the debilitating effects of the low ambiguity tolerance by deliberately increasing their tolerance level.

Contextual guessing strategies are recommended for the identification of the meanings of unknown words in situations where the learner lacks the necessary knowledge of the vocabulary, the grammar or other linguistic elements to understand the text. According to Oxford (1990), contextual guessing strategies are possible due to a wide range of clues: linguistic and non-linguistic. It is valuable for the language learners to recognize that they can decipher the meaning of the unknown words by interpreting their immediate context or the preceding or following words, or even by means of other linguistic clues such as semantic or syntactic knowledge. For the non-linguistic clues, the knowledge of the context, text structure and general worldviews are to be applied. Reflecting on the existing possible guessing strategies gives the reader the certainty that learners must not be discouraged by ambiguities, but that the means for disambiguation are to be found in the same context. The teaching-material designers, as providers of a considerable part of the language learning products, play a fundamental role in facilitating the language learning process. The integration of linguistic strategies, in particular reading strategies with a special focus on ambiguity tolerance as a learning style or compensation strategy in the GFL course books, could enable the language learners to overcome their learning difficulties analytically and deliberately through the application of those strategies.

\section{Acknowledgments}

This work was supported by Research institute ReCeLLT. The authors would like to express their heartfelt gratitude to Parvaneh Sohrabi for her academic support and dedication.

\section{References}

Alderson, J. C. (2000). Assessing reading. Cambridge language assessment series, New York: Cambridge University Press.

Arnold, J. (2011). Attention to Affect in Language Learning. Anglistik. International Journal of English Studies, 22(1), 11-22. Retrieved from http://files.eric.ed.gov/fulltext/ED532410.pdf

Arnold, J., \& Brown, H. D. (1999). A map of the terrain. In J. Arnold (Ed.), Affect in Language Learning (pp. 1-24). Cambridge: Cambridge University Press.

Artelt, C., McElvany, N., Christmann, U., Richter, T., Groeben, N., Köster, J., ... Ring, K. (2007). Förderung von Lesekompetenz-Expertise, 1. Aufl./unveränderter Nachdruck, Berlin: Bundesministerium für Bildung und Forschung. Retrieved from https://www.bmbf.de/pub/Bildungsforschung_Band_17.pdf

Atef-Vahid, S., Fard Kashani, A., \& Haddadi, M. (2011). The relationship between level of ambiguity tolerance and cloze test performance of Iranian EFL lerarners. LiBRI. Linguistic and Literary Broad Research and 
$\begin{array}{llll}\text { Innovation, } & 2(2), & \text { Retrieved } & \text { from }\end{array}$ https://www.edusoft.ro/brain/index.php/libri/article/view/277/368

Babaii, E., \& Shahri, S. (2010). Psychometric rivalry: The C-test and the cloze test interacting with test taker characteristics. In R. Grotjahn (Ed.), Der C-Test: Beiträge aus der aktuellen Forschung (pp. 41-56).

Bachman, L. (1990). Fundamental considerations in language testing. Oxford: Oxford University Press.

Bachman, L., \& Palmer, A. (1996). Language Testing in practice. Oxford: Oxford University Press.

Başöz, T. (2015). Exploring the relationship between tolerance of ambiguity of EFL learners and their vocabulary knowledge. Journal of Language and Linguistic Studies, 11(2), 53-66. Retrieved from http://www.jlls.org/index.php/jlls/article/view/409/219

Brantmeier, C. (2002). Second language reading strategies research at the secondary and university levels: Variations, disparities and generalizability. The Reading Matrix, 2, 1-14. Retrieved from http://www.readingmatrix.com/articles/brantmeier/article.pdf

Brown, H. D. (2000). Principles of language learning and teaching (4th ed.). New York: Pearson Education.

Bruner, J. S., \& Postman, L. (1951). An approach to social perception. In W. Dennis, \& R. Lippitt (Eds.), Current trends in social psychology (pp. 71-118). Pittsburgh: University of Pittsburgh Press.

Carrell, P. L. (1987). Content and formal schemata in ESL reading. TESOL Quarterly, 21, 461-481. https://doi.org/10.2307/3586498

Carrell, P. L., \& Eisterhold, J. C. (1983). Schema theory and ESL reading pedagogy. TESOL Quarterly, 17, 553-573. https://doi.org/10.2307/3586613

Chapelle, C., \& Roberts, C. (1986). Ambiguity tolerance and field independence as predictors of proficiency in English as a second language. Language Learning, 36, 27-45. https://doi.org/10.1111/j.1467-1770.1986.tb00367.x

Covington, M. V. (1997). Self-worth and motivation. New York: Cambridge University Press.

Cronbach, L. J. (1987). Statistical tests for moderator variables: Flaws in analyses recently proposed. Psychological Bulletin, 102, 414-417. https://doi.org/10.1037/0033-2909.102.3.414

Ehrman, M. E. (1996). Understanding second language learning difficulties. Thousand Oaks: SAGE.

El-Koumy, A. S. A. (2000). Difference in Florida Reading Comprehension among High-, Middle-, and Low-Ambiguity Tolerance Students. Education Resources Information Center (ERIC). Retrieved from http://files.eric.ed.gov/fulltext/ED445534.pdf

Ely, C. M. (1989). Tolerance of ambiguity and use of second language learning strategies. Foreign Language Annals, 22(5), 437-445. https://doi.org/10.1111/j.1944-9720.1989.tb02766.x

Ely, C. M. (1995). Tolerance of ambiguity and the teaching of ESL. In J. Reid (Ed.), Learning styles in the ESL/EFL classroom (pp. 87-95). Boston: Heinle \& Heinle. Retrieved from http://researcharchive.wintec.ac.nz/2673/1/Ambiguity.pdf

Erten, I. H., \& Topkaya, E. Z. (2009). Understanding tolerance of ambiguity of EFL learners in reading classes at tertiary level. Novitas Royal, Research on Youth and Language, 3(1), 29-44. Retrieved from http://www.novitasroyal.org/Vol_3_1/erten_topkaya.pdf

Finkbeiner, C. (1997). Zur affektiven und kognitiven Dimension beim Lesen: Bericht von einer Untersuchung zum Zusammenwirken von Interessen und Lernstrategien. Zeitschrift für Fremdsprachenforschung, 8(2), 197-212.

Finkbeiner, C. (2001a). Zur Erforschung attidunaler und affektiver Faktoren beim Lehren und Lernen fremder Sprachen. In C. Finkbeiner, \& G. W. Schnaitmann (Eds.), Lehren und Lernen in Kontext empirischer Forschung und Fachdidaktik (pp. 352-375). Donauwörth: Auer.

Finkbeiner, C. (2001b). Untersuchungsfeld 2: Attitudinale und affektive Aspekte. In H. J. Vollmer, G. Henrici, C. Finkbeiner, R. Grotjahn, G. Schmidt-Schönbein, \& W. Zydatiß (Eds.), Lernen und Lehren von Fremdsprachen: Kognition, Affektion, Interaktion: Ein Forschungsüberblick. Zeitschrift für Fremdsprachenforschung (Vol. 12, No. 2, pp. 65-76).

Finkbeiner, C. (2005). Interessen und Strategien beim fremdsprachlichen Lesen. Wie Schülerinnen und Schüler englische Texte lesen und verstehen. Tübingen: Gunter Narr Verlag. 
Funk, H., Kuhn, C., Demme, S., Winzer, B., Niemann, R., \& Christiany, C. (2007). Studio d. B1. Deutsch als Fremdsprache. Kurs- und Übungsbuch mit Zertifikatstraining. Cornelsen Verlag, Berlin.

Goethe Institute, V. (Ed.). (2015). Zertifikat B1. Deutschprüfung für Jugendliche und Erwachsene. Modellsatz Erwachsene. Goethe-Institut Österreichisches Sprachdiplom (ÖSD) Universität Freiburg/Schweiz.

Grabe, W., \& Stoller, L. F. (2002). Teaching and researching reading. Harlow: Pearson Education.

Isen, A. M. (1984). Towards understanding the role of affect in cognition. In R. S. Wyer, \& J. R. T. K. Skrull (Eds.), Handbook of social cognition (pp. 179-236). Hillsdale, New Jersey: Erlbaum.

Karbalaee Kamran, S., \& Maftoon, P. (2012). An Analysis of the Associations between Ambiguity Tolerance and EFL Reading Strategy Awareness. English Language Teaching, 5(3), 188-196. https://doi.org/10.5539/elt.v5n3p188

Kazamia, V. (1999). How tolerant are Greek EFL learners of foreign language ambiguities? Leeds Working Papers in Linguistics, 7, 69-78. Retrieved from http://www.leeds.ac.uk/linguistics/WPL/WP1999/kazamia

Keshavarz, M. H., \& Assar, M. (2009). Reading Comprehension Ability and Metacognitive Awareness of Reading Strategies among High, Mid and Low Ambiguity Tolerance EAP Students. Archive of SID, 71-108. Retrieved from http://www.sid.ir/en/VEWSSID/J_pdf/125320090204.pdf

Lee, E. K. (1999). The Effects of Tolerance of Ambiguity on EFL Task-Based Writing. The SNU Journal of Education Research, 9, 117-131. Retrieved from http://s-space.snu.ac.kr/bitstream/10371/70570/1/vol9_7.pdf

Lilli, W., \& Frey, D. (1993). Die Hypothesentheorie der sozialen Wahrnehmung. In D. Frey, \& M. Ire (Eds.), Theorien der Sozialpsychologie. Band I: Kognitive Theorien (pp. 49-78). Bern: Huber.

Lustig, M., \& Koester, J. (1993). Intercultural competence: Interpersonal communication across cultures. New York: Harper Collins College Publishers.

Mashkovskaya, A. (2013). Der C-Test als Lesetest bei Muttersprachlern. Dissertation an der Universität Duisburg-Essen.

McLain, D. L. (1993). The MSTAT-1: A new measure of an individual's tolerance for ambigity. Educational and Psychological Measurement, 53, 183-189. https://doi.org/10.1177/0013164493053001020

Miall, D. (1995). Anticipation and feeling in literary response: A neuropsychological perspective. Poetics, 23, 275-298. https://doi.org/10.1016/0304-422X(95)00004-4

Oxford, R. L. (1990). Language Learning Strategies: What Every Teacher Should Know. New York: Newbury House 1 Harper \& Row.

Oxford, R. L. (1992). Who Are Our Students?: A Synthesis of Foreign and Second Language Research on Individual Differences with Implications for Instructional Practice. TESL Canada Journal, 9(2), 30-49. https://doi.org/10.18806/tesl.v9i2.602

Pallant, J. (2011). SPSS Survival Manual. A step by step guide to data analysis using SPSS (4th ed.). Australia: Allen and Unwin.

Schrader, H. (1996). Von Lesern und Texten. Fremdsprachendidaktische Perspektiven des Leseverstehens. Hamburg: Verlag Dr. Kovač.

Shakeri, H. (2012). The Relationship among EFL Learners' Autonomy, Tolerance of Ambiguity, Reading Strategies, and Reading Comprehension (MA-thesis). Islamic Azad University, Central-Tehran branch. Retrieved from http://language.iauctb.ac.ir/Files/275/Thesis/275_2014-1101_10.06.24_Hossein\%20Shakeri\%20Thesis.pdf

Spolsky, B., Bengt, S. M., Sako, E. W., \& Aterburn, C. (1968). Preliminary studies in the development of techniques for testing overall second language proficiency. In J. A. Upshur, \& J. Fata (Eds.), Problems in foreign language testing (Language Learning Special Issue 3, pp. 79-103). Retrieved from http://onlinelibrary.wiley.com/doi/10.1111/j.1467-1770.1968.tb00224.x/pdf

Telc gGmbH. (Ed.). (2014). Übungstest 1. Zertifikat Deutsch. Prüfungsvorbereitung. Frankfurt am Main. Retrieved from http://www.dsh-germany.com/_downloads/certificates/telc/pdf/telc-deutsch-b1-zd-uebungstest.pdf

Underhill, A. (1989). Process in humanistic education. ELT Journal, 43(4). https://doi.org/10.1093/elt/43.4.250 
Vogt, W. P. (2007). Quantitative research methods for professionals. New York: Pearson/Allyn \& Bacon.

White, C. (1999). Expectations and emergent beliefs of self-instructed language learners. System, 27(4), 443-457. https://doi.org/10.1016/S0346-251X(99)00044-5

Ying, Y. (2001). Acquiring vocabulary through a context-based approach. English Teaching Forum, 39(1), 18-26.

\section{Notes}

Note 1. German as a foreign language

Note 2. Second language tolerance of ambiguity scale

\section{Appendix A}

The Questionnaire "SLTAS" (Taken and adapted from Ely, 1995)

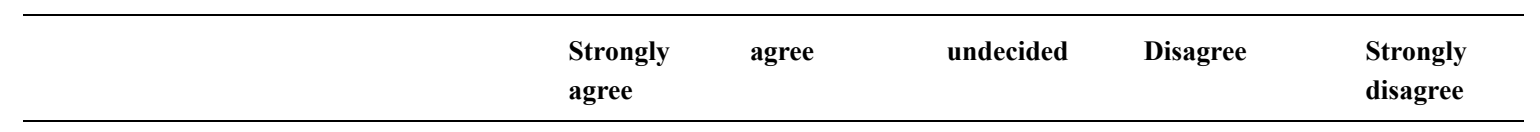

1. When I'm reading something in German, I feel impatient when I don't totally understand the meaning.

2. It bothers me that I don't understand everything the teacher says in German.

3. When I write German compositions, I don't like it when I can't express my ideas exactly.

4. It is frustrating that sometimes I don't understand completely some German grammar.

5. I don't like the feeling that my German pronunciation is not quite correct.

6. I don't enjoy reading something in German that takes a while to figure out completely.

7. It bothers me that even though I study German grammar, some of it is hard to use in speaking and writing.

8. When I'm writing in German, I don't like the fact that I can't say exactly what I want.

9. It bothers me when the teacher uses a German word I don't know.

10. When I'm speaking in German, I feel uncomfortable if I can't communicate my ideas clearly.

11. I don't like the fact that sometimes I can't find German words that mean the same as some words in my own language.

12. One thing I don't like about reading in German is having to guess what the meaning is. 


\section{Appendix B}

\section{Gap-filling-text tests}

Liebe Karin,

nach meinem Praktikum in Frankreich bin ich jetzt wieder zu

Wie du ja weißt, wollte ich eigentlich nach Paris, aber das hat dann leider nicht Doch dann habe ich eine als Praktikant bei einer Firma in Straßburg

Dort bin ich drei Monate geblieben. Die Arbeit war sehr - ich musste schon um 8.00 Uhr im sein -, hat mir aber nicht sehr gut

Ich habe in dieser Zeit in verschiedenen Abteilungen und so nicht nur etwas über die von Fernsehgeräten gelernt, auch über den Verkauf.

Und die. mit denen ich am meisten zu tun hatte, waren wirklich sehr nett.

Nach dem habe ich noch zwei Wochen bei meinen Freunden

gemacht. Darüber ich bald mehr - für heute muss ich Schluss

Liebe Grüße

Fritz (Telc gGmbH, 2014, p. 12)

\section{Hotel-Pension Janosch}

ruhige Lage, Wanderwege, Bademöglichkeiten,

Tennis, Freizeitprogramm für Kinder,

Familienappartements: 1 Woche pro Person

nur $€$ 99,--inklusive Frühstück, spezielle Kinderermäßigung.

Anfragen an: Herbert Janosch, Griesweg 3, A-5020 Innsbruck

Sehr geehrter Herr Janosch,

ich habe Ihre Anzeige gelesen und mich sehr für Ihr Angebot. Ich möchte mit meiner Familie vom 10.-24. August in Österreich machen und hätte deshalb gerne noch nähere

Meine Frau und mich interessiert ganz das Freizeitprogramm für Kinder, da

wir zwei ................. (3 und 8 Jahre) haben. Gibt es Schwimm- und Tenniskurse für Kinder und wenn ja, was kosten sie? In Ihrer steht auch, dass Sie für die Unterkunft Angebote für Kinder haben. Wie viel müssen wir pro Woche für unsere Kinder ?..?

Und noch eine letzte : Wir haben einen kleinen Hund, von dem sich meine Kinder nicht können und den wir auch mitnehmen müssten. Wäre das ...?

Bitte schreiben Sie uns so bald wie möglich, damit wir uns bald entscheiden können. Außerdem wären wir Ihnen sehr ............. , wenn Sie uns einige Prospekte oder Bilder Ihrer Pension sowie der Umgebung zuschicken würden.

Mit .................. Grüßen

Ihr Anton Müller (Telc gGmbH, 2014, p. 13).

Sehr geehrter Herr Luca,

vielen Dank für das kurze Gespräch auf der Bildungsmesse in Köln. Ich hoffe, Sie hatten inzwischen ein bisschen .............., sich Köln anzusehen. Wie Sie ja ................, sind wir ein kleiner Verlag, der aber vor allem im Bereich der Fremdsprachen seit vielen Jahren sehr erfolgreich ist. Wir ................... noch Lehrwerke für alle Schulformen. Mein Vater hat den Verlag in den 70er Jahren Er war überzeugt, dass es immer einen Markt für gute Bücher geben wird. Qualität war für ihn wichtig. Auch heute stehen unsere Bücher für höchste .................. Deshalb ist der Verlag in den letzten Jahren auch so gewachsen. Wir sind vor einem Jahr dann auch in ein neues und größeres Gebäude gezogen, weil wir einfach keinen mehr in unserem alten Haus hatten.

Wir haben ja auf der Messe auch über unser neues DaF-Lehrwerk für Jugendliche Der erste Band ist jetzt Ich habe Ihnen das Buch gestern mit der Post . Ich 
hoffe, es Ihnen. Ich würde Sie zu einem Gespräch in Florenz treffen. Dann wir alle Fragen besprechen. Hätten Sie vielleicht Anfang Juli ??

Mit freundlichen

Holger Behm (Funk et al., 2007, p. 201).

\section{Copyrights}

Copyright for this article is retained by the author(s), with first publication rights granted to the journal.

This is an open-access article distributed under the terms and conditions of the Creative Commons Attribution license (http://creativecommons.org/licenses/by/4.0/). 